This is an author produced version of a book chapter published in The European Landscape Convention : challenges of participation. This version has been peer-reviewed but may not include the final publisher proof-corrections.

Citation for the published chapter:

Larsson, A., Peterson, A., Bjärnborg, E., Haaland, C. \& Gyllin, M. (2011) Regional Landscape Strategies and Public Participation: Towards Implementing the European Landscape Convention in Sweden. In: Jones,

M \& Stenseke, M. (eds.) The European Landscape Convention : challenges of participation. 261-274. Dordrecht : Springer Verlag. (Landscape Series Volume 13)

Published with permission from: Springer Verlag.

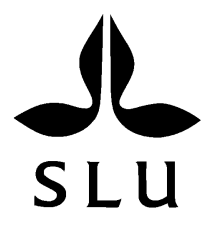

Epsilon Open Archive http://epsilon.slu.se 


\title{
Chapter13
}

\section{Regional Landscape Strategies and Public Participation: Towards Implementing the European Landscape Convention in Sweden}

\author{
Anders Larsson, Anna Peterson, Elinor Bjärnborg, Christine Haaland, \\ and Mats Gyllin
}

\begin{abstract}
Sweden has recently decided to ratify the EuropeanLandscape Convention (ELC). Methods for implementation have been discussed for both the ELC and related national environmental objectives. Thus, the Swedish Government decided that seven County Administrative Boards should undertake pilot studies for Regional Landscape Strategies (RLS) during 2006-2007. The RLS
\end{abstract}

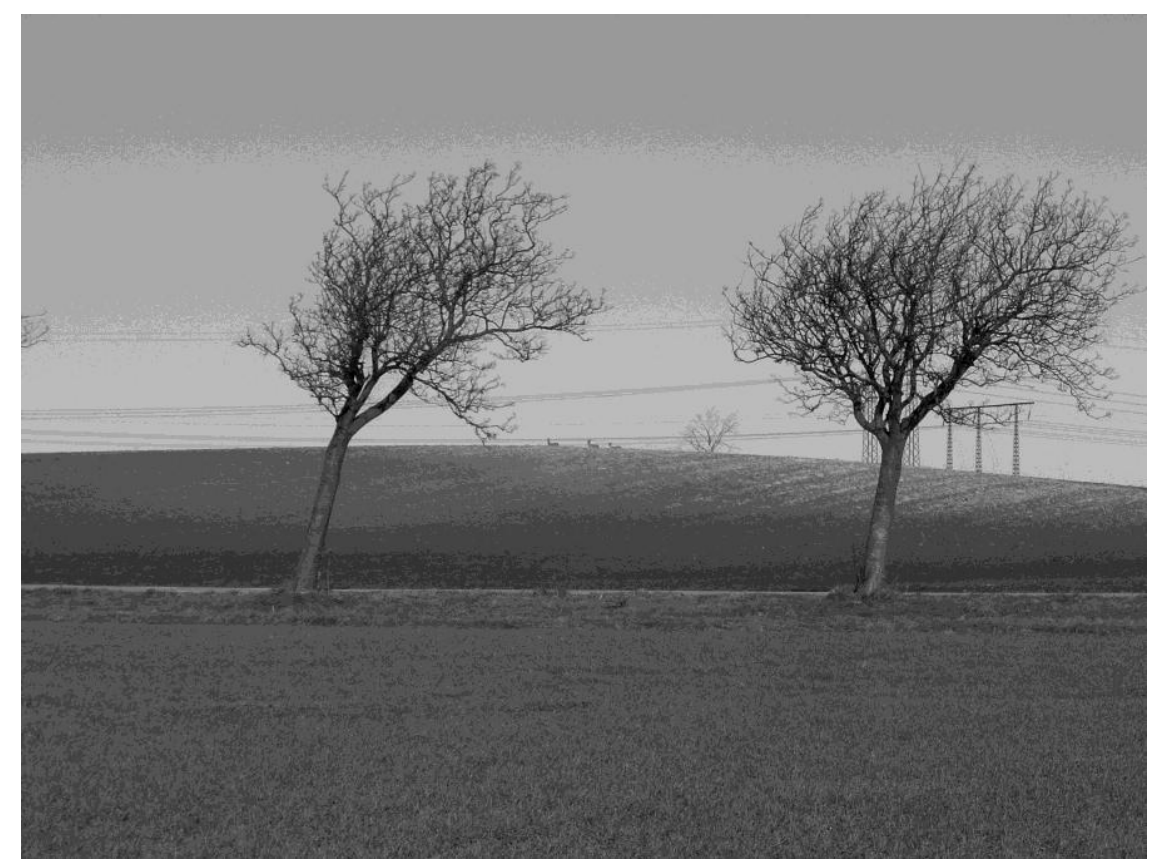

\section{A. Larsson}

Department of Landscape Architecture, Swedish University of Agricultural Sciences, P.O. Box 58, SE-230 53 Alnarp, Sweden

e-mail: anders.larsson@slu.se 
pilot projects aimed at a new and more effective approach for conservation and sustainable land use at regional level. Additionally, RLS should also function as a method for implementing the ELC and other environmental objectives. One specific focus of the pilot studies was on developing methods for public participation. Other important issues were to involve different administrative sectors, municipalities and regional authorities in the process, as well as attaining a good balance between conservation and profitable land use. This chapter presents some of the results from the RLS case study in Vellinge municipality, Scania (Skåne), Sweden's southernmost province. The focus of the study was on public participation in particular by equestrians and landowners. The first 'bridleway organization' of its kind in Sweden was established as a direct result of the project.

Keywords Regional Landscape Strategies, Public Participation, European Landscape Convention, Stakeholders, Multifunctional Greenways, Greenway Planning, Municipal Planning (Sweden), Bridleways, Equestrians, Landowners

\subsection{Introduction}

This chapter presents results and experiences from a pilot study on Regional Landscape Strategies (RLS) in Sweden (Länsstyrelsen, 2007). RLS were suggested by the government as a possible method for implementing both national and international environmental objectives, including the European Landscape Convention (ELC) (Regeringen, 2005a). The aim of the RLS programme was initially to develop methods of operation and planning processes by evaluating a number of pilot studies carried out within the RLS, and then to produce a manual for work with RLS within County Administrative Boards. Important points of departure for the pilot studies were to involve many different administrative sectors, municipalities and regional authorities in the process, and to attain a positive balance between land conservation and utilization. The activities were to be carried out within a public process in which landowners and other representatives from agriculture and forestry, affected organizations, and local stakeholders were invited to participate (Regeringen, 2005b). The Swedish Environmental Protection Agency (Naturvårdsverket) was given responsibility for the RLS projects and their subsequent evaluation, while the Swedish National Heritage Board (Riksantikvarieämbetet) was given responsibility for implementing the ELC.

The national authorities commissioned out the RLS pilot studies to seven County Administrative Boards. The Board in Scania (Skåne), the southernmost region in Sweden, in its turn commissioned out the work to four municipality work-i ng groups, who performed one local pilot study each. The work presented here is the result of one of these local pilot studies, in Vellinge, the southernmost municipality in Scania (Fig. 13.1). The major part of the pilot study was carried out by members of the research project 'Multifunctional Greenways as a tool for strategic landscape planning - proposals for design and implementation in periurban landscapes'. This project studies the phenomenon of Greenway Planning 


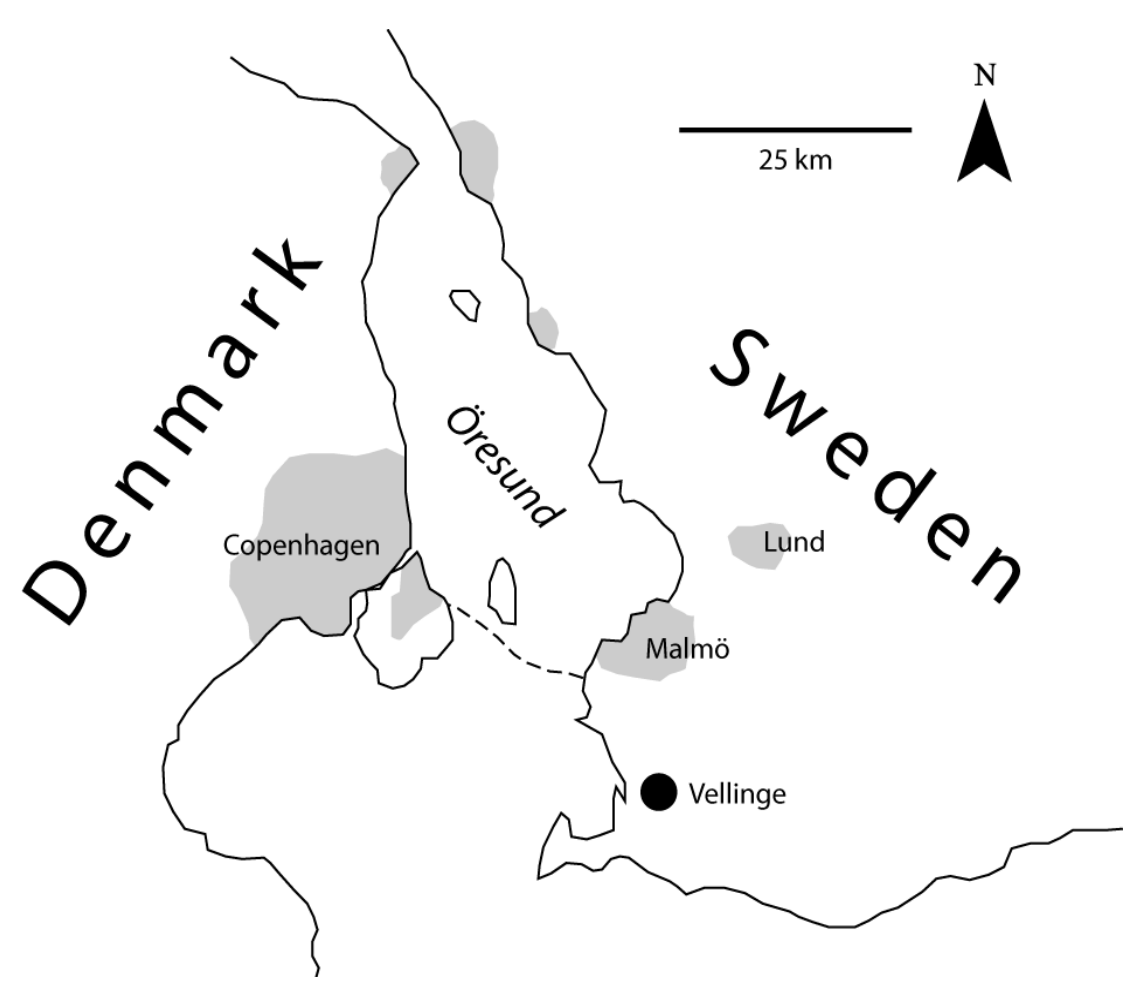

Fig. 13.1 Vellinge, Scania - location of the study area (Map: Mats Gyllin)

from a multitude of perspectives. One of these is the planning perspective, not least aspects concerning public participation. The active participation within the RLS pilot studies gave the researchers an opportunity to experiment and draw preliminary conclusions on one of the aspects covered by the general research project, which was then used as a stepping stone towards a more precise research design. This chapter presents concrete results of the RLS pilot study in Vellinge, especially regarding public participation. This will later be integrated with other findings within the general research project on the formal planning system in Sweden and possibilities for working with strategic Greenway Planning. During the process, the research group was open about their double role as both researchers and coordinators of the RLS pilot study. The involved authorities and individuals accepted the fact that the results of the RLS project would be further analyzed within the general research project.

\subsection{Brief Policy Background: National Environmental Quality Objectives and Regional Landscape Strategies}

In 1999, 15 Environmental Quality Objectives were adopted by the Swedish Parliament with the objective of safeguarding biodiversity and natural environments (Miljömålsrådet, n.d.). The Swedish National Environmental Quality Objectives form an important part of the process of achieving sustainable development, along with the social and economic dimensions involved. These objectives have been 
designed to promote human health, safeguard biodiversity and the natural environment, preserve the cultural environment and heritage, maintain long-term ecosystem productivity and, finally, ensure prudent management of natural resources. All of this is covered in the now 16 specific environmental quality objectives along with their respective interim targets (Miljömålsrådet, n.d.).

The 16th Environmental Quality Objective was added to the list in 2005 (Miljömålsrådet, n.d.) and aims at maintaining a rich diversity of plant and animal life. It states that:

Biological diversity must be preserved and used sustainably for the benefit of present and future generations. Species habitats and ecosystems and their functions and processes must be safeguarded. Species must be able to survive in long-term viable populations with sufficient genetic variation. Finally, people must have access to a good natural and cultural environment rich in biological diversity as a basis for health, quality of life and well-being (Miljömålsrådet, n.d.).

The Environmental Quality Objectives are to be considered within all municipal planning and infrastructure planning in Sweden (see Alfredsson and Wiman, 2001 for a description of the Swedish planning system in English).

Also in 2005, the Swedish government proposed that a group of County Administrative Boards should perform pilot case studies on RLS as tools for implementing interim target 3 (sustainable use of biological resources) of the 16th Environmental Quality Objective (Regeringen, 2005b). RLS was also regarded as a possible method for implementing the ELC in Sweden. The pilot studies were completed in 2007 (Naturvårdsverket, 2008).

The ELC (Council of Europe, 2000) was signed by Sweden in 2001. In 2008, the Swedish National Heritage Board presented their suggestions on how to implement the ELC in Sweden. Two of their recommendations were that Sweden should ratify the ELC as soon as possible and introduce Regional Landscape Strategies (Riksantikvarieämbetet, 2008). In November 2010, the Swedish government decided to ratify the ELC. The compatibility and possible synergy effects between the RLS and the ELC are clear.

The Environmental Quality Objectives will influence the way that the ELC will be implemented in Sweden. Even though 'future generations' and the well-being of people living in the landscapes arementioned, our concern is that the strong Swedish tradition of top-down nature conservation will affect the ELC perspectives on public participation in a negative way.

\subsection{The Vellinge Project}

The County Administrative Board of Scania delegated the RLS pilot studies to a group of municipalities. The county was responsible for the central coordination and the main communicative link between the municipalities and the central author ities. It also contributed its expertise as appropriate. The County Administrative Board of Scania further specified that the RLS projects, besides involving different 
sectors and authorities, balancing between conservation and utilization, and engaging in an open process, should also integrate knowledge about cultural heritage and consider the 'everyday landscape' in order to develop more robust methods for public participation (Länsstyrelsen, 2007). Vellinge was one of the municipalities that announced its interest in taking part in a pilot project and in turn commissioned the coordination of the pilot study to our research group. The project group included both the coordinators and participating staff from the municipality and the County Administrative Board.

It is important to notice that there was a certain ambivalence in objectives since both top-down priorities (biodiversity issues) and bottom-up approaches (local participation) were required to be included in the RLS pilot studies.

Vellinge is situated in an intensive farming region south of Malmö. This is also the part of Sweden where one of the most intensive processes of urbanization is taking place, which has resulted in peri-urban structures and islands of urban settlements surrounded by large fields of inaccessible, arable land (Qviström et al., 2007). There is a great need for green structures and recreational opportunities for the increasing urban population. This part of Sweden is also one of the regions with the highest proportion of horses per capita in the country (Jordbruksverket, 2005). Some biological hot-spots exist, especially along the coastline, but these are not connected within a larger green network (Länsstyrelsen, 2007).

It soon became clear that one of the most important planning problems in Vellinge regarding access to the countryside was how to manage the increasing number of horses, particularly within the urban fringes of highly productive agricultural areas with low accessibility and high pressure on the land (Hautbois and Durand, 2004; Ivarsson, 2008). During the process, the planners in the municipality recognized their lack of expertise and experience in considering such issues. The municipality welcomed equestrians to move to the area but had not hitherto handled any associated conflicts and practical problems (Fig. 13.2). A 'horse village' was planned at the same time as our project was running, but no additional plans had been made for bridleways and access to the surrounding landscape for those who wanted to ride outside the village.

Our project was limited to a period of approximately 6 months. In order to plan constructively for a green infrastructure in the 'everyday landscape' during this time frame, planners within the municipality were asked to identify the most critical and pressing issues. One of the main problems identified was the high number of equestrians having difficulties riding in the intensively farmed landscape. Over time, this had led to hostility between landowners and equestrians. Yet there was no local organization embracing these two interest groups which could have mediated in these conflicts. Farmers are mainly organized at national level in the Federation of Swedish Farmers (Lantbrukarnas Riksförbund - LRF), while equestrians are not organized in any general horse organization.

Hence, the project group decided to concentrate on this specific issue in order to test methods for local participation and transforming conflicts into constructive landscape management, while focusing less on the regional perspective. The specific objective was to attain agreement between landowners and equestrians on how and where to locate bridle paths within the intensively farmed landscape. However, we 


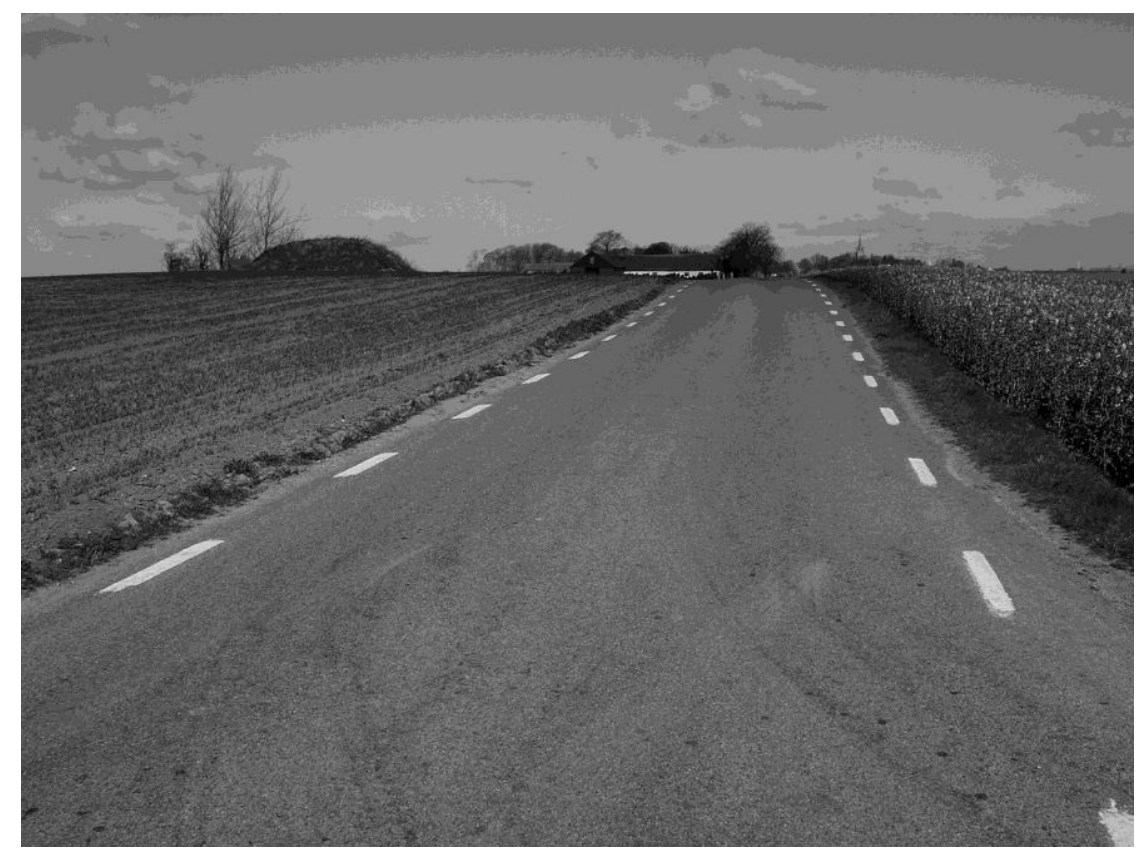

Fig. 13.2 Narrow roads and little space for equestrians in a typical Vellinge landscape (Photo: Courtesy of Daniel Melchert, God Bostad Kulturmiljökonsult)

did not expect to establish bridle paths in the short period of time available for the project.

To improve biodiversity in the intensively used agricultural landscape by a green network system was seen as a further possible positive outcome of arranging bridleways. Thus, aspects of biodiversity were brought into the discussions, but rather as a possible by-product, which could be reached by a certain design of the bridleways. The involved authorities accepted this as a necessary step to take. First an arena for dialogue regarding collaborative landscape management should be established, and then specific issues, like biodiversity, should be attempted to be solved. Local stakeholders (mainly landowners and equestrians) were chosen as the main focus groups, in order to handle the project within the limited time available.

It has not been the authors' intention to evaluate the complete RLS program, but to show the results of a case study concerning public participation and discuss this especially in relation to the implementation of the ELC and national planning processes.

The specific case study in Vellinge was carried out through a series of meetings, including presentations from the researchers and the authorities, listening to arguments from local participants, and discussions and active participation among all interested parties. The external project meetings consisted of a landowner meeting, a general meeting, and an equestrian meeting. In-depth interviews with different stakeholders were subsequently carried out (Bjärnborg, 2007; Länsstyrelsen, 2007). The methodology used was inspired by previous results on communicative aspects in countryside planning (e.g. Larsson, 2004) and literature on stakeholder participation in environmental decision-making (e.g. Bierle, 2002). Specific details 
regarding the process were elaborated in cooperation with the municipal planners. The method might best be described as a modified traditional planning process with active participation by local stakeholders at the beginning of the process instead of a more passive transfer of knowledge and information in the middle and at the end of the process. There were no ready plans for the local participators to react upon. This model has been described by Axelsson (2009), who summarizes the most important aspects to consider as:

1. An area that fits with the main sustainability gaps or tasks at hand (discussed beforehand with municipal planners)

2. Collaboration among actors and stakeholders (main issue discussed at all meetings)

3. A commitment to sustainable development and sustainability profiles as a result of analysis (main objective and outcome of the equestrian meeting)

4. Knowledge production to learn about the area, solve sustainability issues, and improve practices (issues at the landowner and general meetings)

5. A systematic approach to sharing, including networking (all meetings in combination).

The municipality was the formal host of all of the meetings. The project leaders from the County Administrative Board participated but maintained a low profile since they were not a part of the landowner versus equestrian conflict. They acted as observers and experts who could be approached regarding specific questions regarding, for example, biodiversity issues (Länsstyrelsen, 2007).

\subsection{Results}

All results below, except post-project results, have been extracted from the Vellinge report, Appendix 5 of the RLS assignment (Länsstyrelsen, 2007).

\subsubsection{Landowner Meeting}

The first meeting was held with landowners, since it was essential to get their supPort for the rest of the process. Nearly all the landowners in the area were present at this meeting. They were worried about their land and wanted to ascertain that nothing they did not approve of was going to be carried out. The project group was able to clarify that we had not made any concrete plans for bridle paths. The farmers had, as anticipated, a great deal to say about the equestrians. According to the farmers, equestrians went riding everywhere and had little or no respect for private land or growing crops.

The matter of 'responsibility' was a particular concern. The landowners wanted to know the exact rules concerning private land, the right of public access (allemansrätten), and who was to be held responsible for any possible accidents. As a result, 
project members from the County Administrative Board researched some of the legal issues and organized a lecture on the topic of allemansrätten for the following meeting, where the equestrians also participated.

Economic considerations were important. Landowners wanted to be compensated for any bridle paths on their land. We validated their concern and told them that both the issue of proper compensation and redirecting the equestrians to more suitable riding places could be positive outcomes of a process of negotiation. If nothing was done about the present situation, landowners would risk having people and horses all over their properties.

The project group witnessed a lot of frustration from the landowners. However our focus was always on objective listening and encouraging further involvement, not arbitrating the situation. Paradoxically, the landowners were especially frustrated by the fact that there were no existing municipal plans to discuss with the authorities. The landowners were not used to the form of procedure adopted, involving participation at an early stage. Typically, they were used to being contacted by the authorities at a much later stage in the planning process.

\subsubsection{General Meeting}

Second, a general meeting was arranged, where all the local residents were invited. Not unexpectedly, the topic attracted mainly equestrians and landowners, but also members of local heritage organization and persons interested in recreational issues in general took part. Posters concerning biodiversity were presented and short lectures on such topics were held. Experts from the County Administrative Board provided information regarding nature reserves and thereby represented the 'green' perspective. A short lecture on the right of public access was delivered by a representative from the County Administrative Board. A questionnaire was also handed out, in which issues regarding biodiversity gained relatively low scores. Discussions at this meeting, and elsewhere, also clearly indicated this; the local residents did not place 'biodiversity' as high on the list of important issues to solve as did the invited experts from the various authorities.

This meeting resulted in a very fruitful exchange of perspectives between landowners and equestrians (Fig. 13.3). Both parties gained insight into each other's perspectives and discussed possible solutions for the future. The message from the project group was that status quo would not be a positive solution. We also stated that that the landowners and equestrians had equal responsibility for reaching a resolution. At the end of this meeting, some of the initially most aggressive farmers stated that they might actually agree to lease some of their land to the equestrians, especially if this would mean that equestrians would no longer be riding over other parts of their land. The equestrians, in turn, said that it would be possible for them to pay farmers for the benefit of riding on bridle paths, and that they would consider introducing some kind of 'driver's licence' for equestrians before they would be permitted to ride along these paths. 


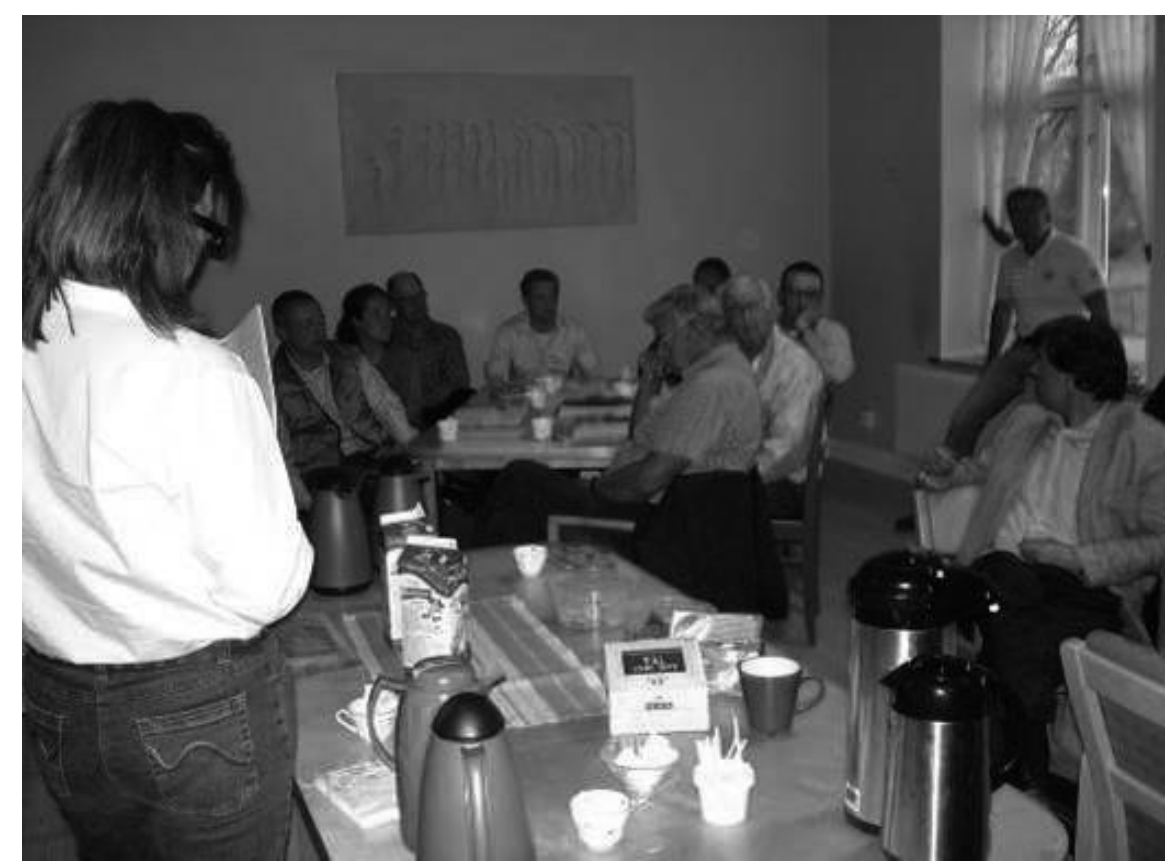

Fig. 13.3 Public participation meeting with landowners and equestrians in Vellinge (Photo: Daniel Melchert, God Bostad Kulturmiljökonsult)

\subsubsection{Equestrian Meeting}

The project group agreed that it would be necessary for the long-term continuation of the project to be quite frank with the equestrians. We told them that from now on it would be up to them to take responsibility for the process in the future. We found it encouraging that the equestrians created a group for riders where they could meet and discuss issues at hand. Hence, a final meeting where only equestrians were invited was arranged. Only a few equestrians attended this meeting, but within this group there were representatives from both boarding stables and a riding school. As a result of this meeting, the equestrians decided to get better organized and begin the process of negotiating with landowners.

\subsubsection{In-Depth Interviews with Farmers and Equestrians}

Subsequent interviews were held with two farmers and two equestrians who had parTicipated in the general meeting. The aim of these interviews was to investigate what some of the participants had experienced in the project so far and to ascertain their reasoning about public participation or the process of collaboration in their everyday landscape. These interviews also provided an opportunity for deeper insight into what the participants, relative to their background, perceived as their role in the project, as well as any opportunities and threats they had experienced as a result. 
The in-depth interviews revealed that both the farmers and the equestrians were interested in public participation in order to build a common overview of the situation, and to find solutions. They saw public participation as a means of reaching an improved understanding between the various stakeholders. Even so, the farmers were clear that they were not willing to let anyone else make decisions that concerned their private land. The farmers were worried about anything that could threaten their agricultural businesses.

\subsubsection{Post-project Results}

Although the intentions of the project group did not encompass the establishment of bridle paths, the project did make progress in this direction in the course of its limited duration. A joint organization consisting of both landowners and equestrians was established less than 6 months from the initial landowner meeting. This organization started to discuss how and where to establish bridle paths, and how to solve other practical issues. Farmers agreed to lease land to equestrians, and the equestrians agreed to introduce 'driver's licences' to their members. Some 9-12 months later, the negotiation process seemed to have terminated, allegedly due to lack of discretionary time for residents to organize these efforts and due to the fact that some of the key individuals in the group had moved out of the region. However, the process later on turned out to have gained enough momentum to continue by itself. The first bridleway organization (ridstigsförening) of its kind in Sweden has been established (Vellinge Ridstigsförening, n.d.). This is a positive result considering the extremely short time available and the initial conflict, and clearly illustrates how public participation can be productive in many aspects.

\subsection{Possibilities}

The municipal planners hope that the new joint bridleway organization and the process of starting it, might provide a role model for a consultative body for the municipality regarding future proactive planning projects in the region. If stakeholders are invited to participate at early stages of planning processes, this could result in a more constructive dialogue than within the traditional planning process, where stakeholders chiefly respond to plans already initiated by the experts. This is consistent with results from other participative municipal planning initiatives (Boverket, 2007). Thus, public participation could provide both democratic and economic value.

In Sweden about $85 \%$ of horses are used for recreation (Persson, 2003). These horses and their owners are seldom registered in any organization. The equestrians are individualists, who spend discretionary time on their horses and do not recognize any benefits from organizing within groups. In the Vellinge project their understanding and willingness to participate came from the possibility of better access to riding paths (Fig. 13.4). Many potential bridleways had been closed off by landowners, and 


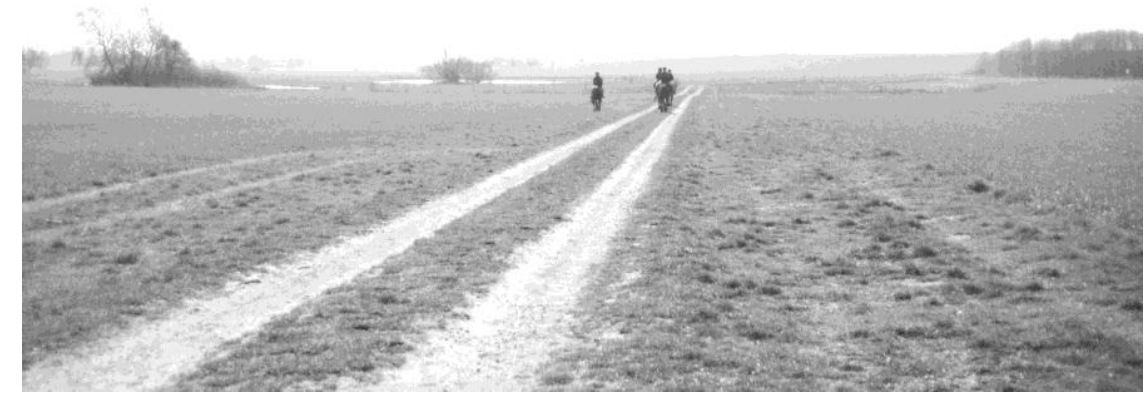

Fig. 13.4 Equestrians on a field road in a typical Scanian landscape (Photo: Mats Gyllin)

equestrians would not allow their children to ride on the roads for safety reasons. Now they saw a chance to get old ways re-opened in addition to new and safer riding possibilities. It became clear that up until the start of our project, landowners had deliberately tried to get horses off their land because a few equestrians had behaved inappropriately while riding. Therefore, the equestrians decided to adopt collective management rules and standardized guidelines for how equestrians in the area should behave. Landowners would be able to consult these regulations when problems arose - before a situation turned into personal conflict.

Farmers maintain that farming is the most appropriate and rational land use. One of the equestrians stated that public participation could be a way of improving stakeholders' involvement. This participation could broaden the view of how to use the landscape for various purposes and alternative ways of earning income from the land. Both landowners and equestrians agreed that the process was beneficial for understanding more about the other parties and their situation. Furthermore, the establishment of bridle paths might create opportunities for developing more advanced multifunctional greenways in the future, which could also lead to an improvement of biological diversity and possibilities for other recreation than horse-riding.

\subsection{Further Experiences}

Other findings indicate that, however desperate the situation might seem at the outset, conflicts should not be avoided but rather dealt with as soon as possible 
(Boverket, 2007). A process will be less constructive if conflict issues are withheld from the negotiating table. Consensus is not a prerequisite for reaching positive results (Hagen, 2006; Nordström, 2008). This contradicts some of the communicative planning theories (e.g. Healey, 1997), which are focused on consensus as both an objective and a method. Another positive aspect of the RLS project was the focus on the 'everyday landscape', as opposed to the tradition of focusing on landscapes and objects of especial value. The focus on the everyday landscape is proactive rather than reactive.

It was clear that issues concerning biodiversity were not of concern for the public taking part in the project. This suggests that biodiversity issues are more of interest for experts or for a minority of layman rather than for the general public, at least when it comes to concrete implementation situations. Policies such as the national Environmental Quality Objectives and the ELC might benefit from using a more concrete terminology in order to reach the minds of the public and, thus, be more in line with additional objectives on public participation. However, local residents are foremost concerned about local and personal issues, which affect their immediate surroundings, their economy, etc. Hence, common and shared values, as well as regional considerations, still need to be safeguarded by the authorities. This might seem a contradiction in terms, but conforms to the results of previous studies of agro-environmental policies, which show that the issue is not a question of discussing public participation as something in opposition to interventions from the authorities. All parties involved need to take their part of responsibility in order for the outcome to become as productive as possible and in order to increase dialogue and respect between experts and laymen (Larsson, 2004). This does not indicate a failure of the participatory procedures adopted, or that issues regarding biodiversity cannot also be handled within such a process given another focus or more time, etc., but rather that there is no single method that can solve all issues. Methodological diversity is needed.

Today, the first official RLS are being implemented (2009-2010), and as expected the focus on the ecosystems approach has increased. Therefore, we find it important to emphasize the importance of public participation for improving the quality of the biodiversity in industrial-agricultural landscapes near cities where urban sprawl occurs and where there is strong competition for land as well as lack of recreational areas.

\subsection{Conclusions}

There are many positive aspects of the RLS, such as the attention to everyday landscapes and the increased focus on local participation. However, the traditional, comprehensive plans also include aspects such as how to improve biodiversity in everyday landscapes, especially where there is a complementary municipal green plan. Dialogue with stakeholders and local interest groups, including landowners, is also part of most Swedish planning processes (road planning, municipal land-use 
planning, etc.). The new focus of the RLS has been on early and active participation rather than (passive) response later in the decision-making process. However, such aspects of the ELC and the Environmental Quality Objectives could have been implemented by minor administrative and juridical modifications of the current planning system, rather than introducing a completely new package of general policy objectives.

Active public participation proved to be productive in many aspects. Farmers, who were usually hostile towards equestrians, learned a great deal about the equestrian perspective and started to think more constructively how to solve problems for the mutual benefit of both parties. Equestrians, who normally regarded the landowners as stubborn, old farmers, with little knowledge about other issues than farming, soon realized obvious benefits from better communication with the landowners and among themselves. Public participation does not solve every planning problem, but might be very productive in addressing specific, local conflicts where closer cooperation between different parties is essential for moving towards the next step in the planning process. Such conflicts cannot be solved by a top-down approach, and neglecting them will only lead to increasing problems later on in the process. Democracy comes at a cost. Nonetheless, public participation in early stages of planning processes might be the best way to maximize the democratic outcome, while at the same time optimizing planning from an economic point of view. People feel much more engaged in the process when asked to participate from the start rather than just to comment upon the work of experts, Early participation also leads to fewer appeals within later stages of the planning process and, thus, lower total costs due to smoother processes. This has been presented in case studies at planning conferences (Boverket, 2007), but needs further scientific studies. It is nevertheless our strong belief that, when local stakeholders resolve their own conflicts, they also make good use of the everyday landscape where they are living. Planners might then also have more time to engage themselves in other relevant environmental problems that need more of the planners' specific attention and expert competence.

Acknowledgments The study was carried out with financial support from the Swedish Research Council Formas, the County Administrative Board of Scania and Vellinge Municipality. We are grateful to administrators in the latter two organizations who have contributed with their time and knowledge.

\section{References}

Alfredsson B, Wiman J (2001) Planning in Sweden - fundamentals outlined. In: Christoferson I (ed) Swedish planning - in times of diversity. Swedish Society for Town and County Planning, Gävle, pp 117-120

Axelsson R (2009) Landscape approach for sustainable developmant - from applied research to transdisciplinary knowledge production, acta universitatis agriculturae sueciae 2009:94. School for Forest Engineers, Swedish University of Agricultural Sciences, Skinnskatteberg

Bierle TC (2002) The quality of stakeholder-based decisions. Risk Anal 22(4):739-749

Bjärnborg E (2007) Samverkan och dialog i landsbygdens landskap, Examensarbeten inom landskapsarkitektprogrammet 2007:29. Sveriges lantbruksuniversitet, Alnarp 
Boverket (2007) Hur bygger vi staden? Dokumentation från Boverkets Plan- och byggdagar 3-5 september 2007 (DVD). Boverket, Karlskrona

Council of Europe (2000) The European landscape convention, Florence, 20.X.2000, ETS No. 176 http://conventions.coe.int/Treaty/en/Treaties/Html/176.htm. Accessed 30 Jan 2010

Hagen A (2006) Practice seeking understanding: a study of county planning in oppland 1974-1996 - Praksis søker forståelse: Studie av fylkesplanlegging i Oppland 1974-1996, Doctor Scientiarum (Dr.Scient.) Thesis, 2006:20. Norwegian University of Life Sciences, Department of Landscape Architecture and Spatial Planning, Ass

Hautbois C, Durand C (2004) Public strategies for local development: the effectiveness of an outdoor activities model. Manag Leis 9(4):212-226

Healey P (1997) Collaborative planning - shaping places in fragmented societies. Macmillian, London

Ivarsson M (2008) Framtidsspaning om hästsektorn, Report. Jordbruksverket. http://www. margaretaivarsson.se/margareta/documents/framtidsspan.pdf. Accessed 30 Jan 2010

Jordbruksverket (2005) Kartläggning och analys av hästverksamheten i Sverige. Jönköping

Länsstyrelsen i Skåne län (2007) Det regionala landskapsstrategiuppdraget, Länsstyrelsens missiv 2007-12-19, inklusive bilagor (CD), Malmö

Larsson A (2004) Landskapsplanering genom jordbrukspolitik: En kritisk granskning av EU:s agrara miljöstödspolitik ur ett planeringsperspektiv, Acta Universitatis agriculturae Sueciae 442. Department of Landscape Planning, Swedish University of Agricultural Sciences, Alnarp

Miljömålsrådet (n.d.) Environmental objectives portal. http://www.miljomal.nu/EnvironmentalObjectives-Portal/. Accessed 11 Nov 2010

Naturvårdsverket (2008) Landskapsstrategier i sju pilotlän 2006-2007: En utvärdering av pilotprojektens organisation och arbetssätt, Rapport 5906. Naturvårdsverket, Stockholm. http://www.naturvardsverket.se/Documents/publikationer/978-91-620-5906-4.pdf. Accessed 14 Apr 2010

Nordström S (2008) Illusionernas harmoni - Samhällsplanerandets tankestil och dess kraftfullaste topos: Diskrepansförnekandet. Doktorsavhandling. Karlstad University Studies 2008:55. Fakulteten för samhälls- och livsvetenskaper, Kulturgeografi, Karlstads universitet, Karlstad

Persson H (2003) Planering för tätortsnära ridning - Mer än bara ridhus, Specialmeddelande 244 Institutionen för jordbrukets biosystem och teknologi (JBT), Sveriges lantbruksuniversitet, Alnarp

Qviström M, Larsson A, Ode A (2007) Peri-urban landscape analysis as a strategic instrument in environmental planning. In: 18th international annual ECLAS conference, Belgrade, Department of Landscape, Architecture and Horticulture, Faculty of Forestry, Belgrade, pp 43 50

Regeringen (2005a) Svenska miljömål - Ett gemensamt uppdrag, Prop. 2004/05:150. Miljö- och samhällsbyggnadsdepartementet, Stockholm

Regeringen (2005b) Regleringsbrev för budgetåret 2006 avseende Länsstyrelserna. Finansdepartementet, Stockholm

Riksantikvarieämbetet (2008) Förslag till genomförande av den europeiska landskapskonventionen i Sverige: Slutredovisning av regeringsuppdrag, Stockholm

Vellinge Ridstigsförening (n.d.) http://www.vellingeridstig.se/ Accessed 14 Apr 2010 